\section{Fla. 7907C: A Fla. 7907 Near-isogenic Tomato Inbred Line Containing the Begomovirus Resistance Gene, Ty-1}

\author{
Samuel F. Hutton ${ }^{1}$ and John W. Scott \\ University of Florida, Institute of Food and Agricultural Sciences (IFAS), \\ Gulf Coast Research and Education Center, 14625 CR 672, Wimauma, FL \\ 33598
}

Additional index words. Solanum lycopersicum, backcross breeding, Tomato yellow leaf curl virus (TYLCV) resistance, fusarium wilt race 3, Fla. 8153, Tasti-Lee

Fla. $7907 \mathrm{C}$ is a Begomovirus-resistant, fresh-market tomato (Solanum lycopersicum) inbred breeding line that is nearly isogenic to Fla. 7907, a parent of 'Fla. 8153' (Scott et al., 2008). The 'Fla. 8153' hybrid is currently grown and sold as a premium vine-ripe tomato under the Tasti-Lee ${ }^{\circledR}$ brand name. However, the lack of Begomovirus resistance in 'Fla. 8153' can limit production in environments where these viruses are problematic. Of the many Begomoviruses that are vectored by the sweetpotato whitefly (Bemisia tabaci), the strains that cause Tomato yellow leaf curl virus (TYLCV) are the most widespread and well known. Begomovirus resistance in Fla. 7907C is conferred by the Ty-1 gene, which was advanced using markerassisted selection through seven rounds of backcrossing to Fla. 7907B. This gene is widely used in hybrid tomato breeding because it is dominant and confers a high level of resistance to TYLCV. Fla. $7907 \mathrm{C}$ combines Begomovirus resistance with the original characteristics of Fla. 7907, and should be useful as a parent in the development of a Begomovirus-resistant version of 'Fla. 8153', and in other hybrid combinations.

\section{Origin}

The pedigree of Fla. 7907C is shown in Fig. 1. Virus resistance was derived from an $\mathrm{F}_{3}$ recombinant inbred line (RIL) developed from the commercial hybrid, Tygress. This hybrid is heterozygous for a very large wildspecies introgression $(\approx 30 \mathrm{Mb})$ on chromosome 6 , which resulted from recombining nematode resistance $(\mathrm{Mi})$ with Begomovirus resistance $(T y-1)$. The selected $\mathrm{F}_{3}$ RIL, however, is the product of two consecutive crossing-over events that trimmed the introgression above and below the $T y-1$ gene, resulting in a much smaller $T y-1$ introgression $(\approx 1 \mathrm{Mb})$ without nematode resistance. This RIL was used for building populations

Received for publication 2 Feb. 2017. Accepted for publication 5 Mar. 2017.

We thank Dolly Cummings, Reza Shekaste band, Tim Davis, and Jose Diaz for their technical assistance.

${ }^{1}$ Corresponding author. E-mail: sfhutton@ufl.edu. to fine-map $T y-1$, and its development is described by Verlaan et al. (2013).

A marker-assisted backcrossing approach was used to introgress $T y-1$ into Fla. 7907B. The reason that the Fla. 7907B background was used instead of Fla. 7907 is because some seed lots of the latter were previously determined to be segregating for resistance to fusarium wilt race 3 (I-3; J.W. Scott, unpublished data); Fla. 7907B is an advanced inbred selection from Fla. 7907, from which a homozygous $I-3$ selection was made in 2007. Six rounds of backcrossing were used to develop a $T y-1$ near-isogenic line of Fla. 7907B. Field evaluations were conducted over multiple seasons during the inbreeding generations at the $\mathrm{BC}_{4}, \mathrm{BC}_{5}$, and $\mathrm{BC}_{6}$. For these evaluations, backcross lines were compared with the Fla. 7907B recurrent parent and selected for trueness-to-type. In Spring $2015, \mathrm{BC}_{6} \mathrm{~F}_{2}$ plants were selected to obtain homozygosity for $T y-1$, and $\mathrm{BC}_{6} \mathrm{~F}_{4}$ seed was bulked in Fall 2016.

\section{Description}

Being a nearly -isogenic line, Fla. 7907C is virtually identical to its recurrent parent. The fruit are deep round (globe) in shape and have a deep red internal color due to the presence of the crimson gene $\left(\operatorname{og}^{c}\right)$. In Fall

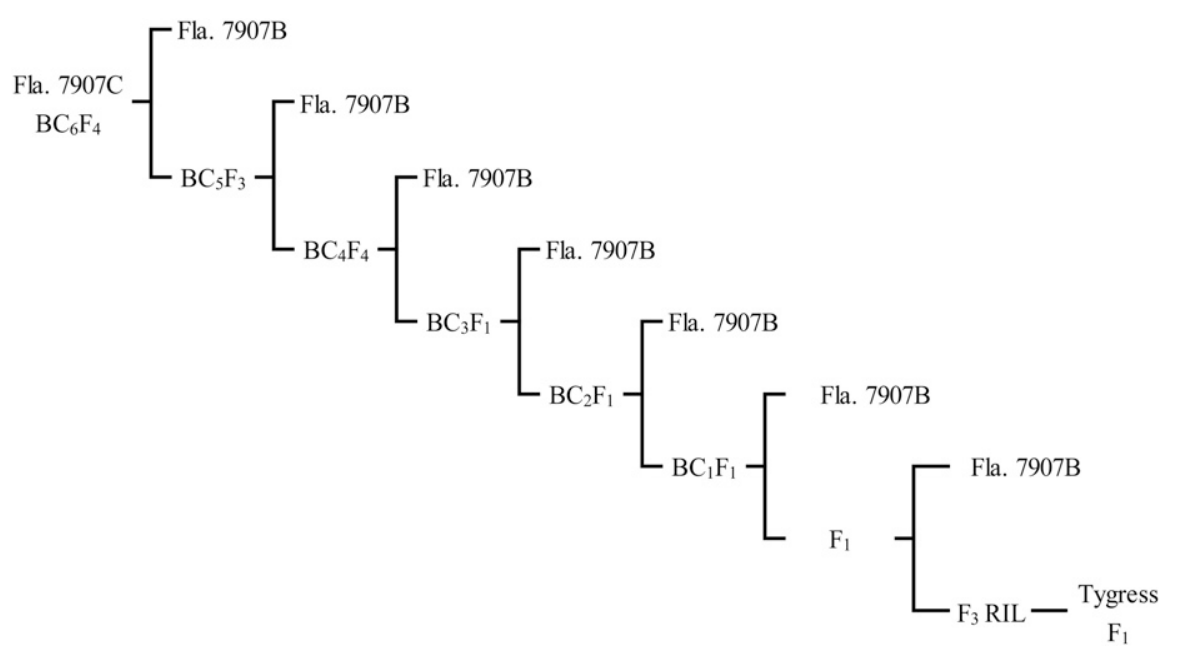

Fig. 1. Pedigree of Fla. 7907C.
2016, comparisons were made among Fla. 7907B, Fla. 7907C (homozygous Ty-1), and the hybrid between these (heterozygous $T y-1$ ) for fruit brix, firmness, and color, to determine if the $T y-1$ allele had any negative effect on fruit quality. In general, fruit quality of Fla. $7907 \mathrm{C}$ and the $\mathrm{F}_{1}$ was similar to that of Fla. 7907B; differences were only observed for brix, external $\mathrm{L}$ values, and internal hue angle (Table 1). Brix was not negatively affected by introgression of the resistance gene; rather, higher brix measurements were observed in the $T y-1$ homozygote and heterozygote than in the recurrent parent. Likewise, the differences observed for internal hue angle suggest that the fruit of Fla. 7907C and the $T y-1$ heterozygote were slightly more red. Fruit of Fla. 7907C had a somewhat lighter exterior color than those of Fla. $7907 \mathrm{~B}$, but the $T y-1$ heterozygote was not significantly different from Fla. 7907B for this trait. Based on these results, there is no evidence that fruit quality would be compromised in hybrids made with Fla. 7907C vs. hybrids made with Fla. 7907B.

The hybrid between Fla. 7907C and Fla. 8059 (Fla. $8153+$ Ty1) is likewise similar to Fla. 8153. The vine of Fla. $8153+$ Ty1 is determinate and maintains good fruit cover but can be slightly taller/more vigorous than the vine of Fla. 8153 (data not shown); this characteristic is commonly observed among lines carrying $T y-1$ (S.F. Hutton, unpublished data) and does not seem to negatively affect the performance of this hybrid. Total and extra-large yields of Fla. $8153+$ Ty1 were not significantly different from those of 'Fla. 8153' across three seasons of testing (Table 2). Percentages of culled fruit were also not significantly different for two of these seasons, although Fla. $8153+$ Ty1 had slightly more culls in Fall 2015 (Table 2). The use of Fla. 7907C in making a TYLCVresistant hybrid with Fla. 8059 had no apparent negative effect on fruit quality (Table 4). Fruit firmness in Fla. 8153 + Ty1 was comparable to that of 'Fla. 8153', and external fruit color was indistinguishable between the two hybrids (Table 3). Internally, fruit of 
'Fla. 8153' and Fla. $8153+$ Ty1 had lower L and hue angles than fruit of 'Florida 47' or 'HM1823', reflecting the deeper red color due to homozygosity for the crimson. Internal fruit color of Fla. $8153+$ Ty1 tended to be slightly darker and slightly redder than that of 'Fla. 8153'. No differences in fruit flavor were observed between Fla. $8153+$ Ty1 and
'Fla. 8153' based on informal assessments made by two or more individuals in each of the 19 hybrid trials conducted over 4 years of testing (data not shown).

Table 1. Brix, firmness, external color, and internal color for fruit of Fla. 7907B, Fla. 7907C, and the hybrid between these two.

\begin{tabular}{|c|c|c|c|c|c|c|}
\hline \multirow{2}{*}{ Line } & \multirow{2}{*}{ Brix } & \multirow{2}{*}{ Firmness $^{\mathrm{z}}$} & \multicolumn{4}{|c|}{ Fruit color $^{y}$} \\
\hline & & & \multicolumn{2}{|c|}{ External } & \multicolumn{2}{|c|}{ Internal } \\
\hline Fla. 7907B & $4.13 \mathrm{c}^{\mathrm{x}}$ & 3.107 & $39.67 \mathrm{~b}$ & 41.88 & 33.74 & $35.00 \mathrm{a}$ \\
\hline Fla. $7907 \mathrm{C}$ & $4.61 \mathrm{a}$ & 3.089 & $41.23 \mathrm{a}$ & 41.83 & 33.84 & $33.77 \mathrm{ab}$ \\
\hline
\end{tabular}

${ }^{\mathrm{z}}$ Determined with a pressure tester of the Institute of Food and Agricultural Sciences using a 1-kg weight for $5 \mathrm{~s}$ with a fruit contact plate $1.5 \mathrm{~cm}$ in diameter. Pressure applied over a locule in equatorial plane. Lower values indicate greater firmness.

${ }^{\mathrm{y}}$ Data taken with a Minolta CR-300 Chroma Meter; higher "L" numbers indicate lighter color (value), lower hue angles indicate more red color (hue).

${ }^{\mathrm{x}}$ Mean separation in columns using Duncan's multiple range test at $P \leq 0.05$. The experiments were completely randomized block designs with two blocks and six-plant plots. Twelve fruit per plot were harvested at the table-ripe stage and used for color and firmness measurements.

Table 2. Marketable yield and culls for selected tomato hybrids harvested at the vine-ripe stage over three seasons at the Gulf Coast Research and Education Center, Balm, FL.

\begin{tabular}{|c|c|c|c|c|}
\hline \multirow[b]{2}{*}{ Season } & \multirow[b]{2}{*}{ Hybrid } & \multicolumn{2}{|c|}{ Marketable yield (11.34 kg cartons/ha) } & \multirow[b]{2}{*}{ Culls (\% by wt) } \\
\hline & & Total & Extra-large & \\
\hline \multirow{2}{*}{ Fall 2016} & Florida 47 & 2,492 & $1,353 \mathrm{ab}$ & 37 \\
\hline & Fla. 8153 & 1,806 & $501 \mathrm{c}$ & 42 \\
\hline \multirow[t]{2}{*}{ Fall 2015} & Solar Fire & 5,298 & $2,863 \mathrm{a}^{\mathrm{z}}$ & $26 \mathrm{~b}$ \\
\hline & Florida 47 & 3,381 & $1,919 \mathrm{~b}$ & $45 \mathrm{a}$ \\
\hline \multirow[t]{5}{*}{ Spring 2015} & Fla. 8153 & 3,678 & $1,635 b^{z}$ & $8 \mathrm{~b}$ \\
\hline & Solar Fire & 3,443 & $2,443 \mathrm{ab}$ & $15 \mathrm{~b}$ \\
\hline & Florida 91 & 3,018 & $2,954 \mathrm{a}$ & $18 \mathrm{~b}$ \\
\hline & Fla. $8153+$ Ty 1 & 2,984 & $1,727 \mathrm{ab}$ & $9 \mathrm{~b}$ \\
\hline & Florida 47 & 2,554 & $2,201 \mathrm{ab}$ & $34 \mathrm{a}$ \\
\hline
\end{tabular}

${ }^{\mathrm{z}}$ Mean separation in columns within seasons by Duncan's multiple range test at $P \leq 0.05$. The experiment was a completely randomized block design with two blocks and eight-plant plots in 2015 and with three blocks and eight-plant plots in 2016.

Table 3. External color, internal color, and firmness for fruit of Fla. 8153, a TYLCV-resistant isoline of this hybrid (Fla. 8153 + Ty1), and comparison tomato cultivars at the Gulf Coast Research and Education Center, Balm, FL, in Fall 2016.

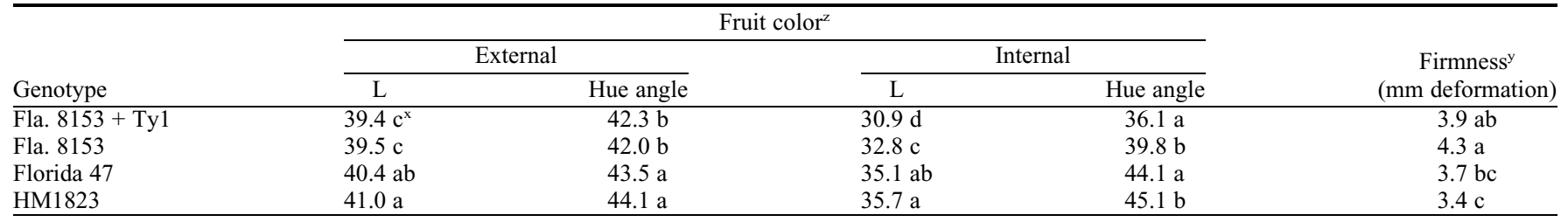

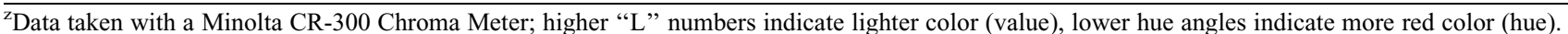

${ }^{\mathrm{y}}$ Determined with a pressure tester of the Institute of Food and Agricultural Sciences using a 1-kg weight for $5 \mathrm{~s}$ with a fruit contact plate $1.5 \mathrm{~cm}$ in diameter. Pressure applied over a locule in equatorial plane. Lower values indicate greater firmness.

${ }^{\mathrm{x}}$ Mean separation in columns using Duncan's multiple range test at $P \leq 0.05$. The experiments were completely randomized block designs with three blocks and eight-plant plots. Ten fruit per plot were harvested at the breaker stage and ripened in a laboratory at $24{ }^{\circ} \mathrm{C}$ until table ripe for color and firmness measurements.

Table 4. Marketable yield, culls, and TYLCV disease severity of inoculated hybrids grown at the Gulf Coast Research and Education Center, Balm, FL, in Fall 2016.

\begin{tabular}{lccc}
\hline & \multicolumn{2}{c}{ Marketable yield (11.4 kg box/ha) } & \\
\cline { 2 - 3 } Hybrid & Total & Extra-large & Culls (\% by wt) \\
HM 1823 (heterozygous Ty3) & $7,918 \mathrm{a}^{\mathrm{y}}$ & $4,418 \mathrm{a}$ & $14 \mathrm{ab}$ \\
Fla. 8970 (heterozygous Ty1) & $7,382 \mathrm{a}$ & $4,077 \mathrm{ab}$ & $12 \mathrm{ab}$ \\
Fla. 8153 + Ty1 (heterozygous) & $6,876 \mathrm{a}$ & $3,240 \mathrm{ab}$ & $2.1 \mathrm{~b}$ \\
Fla. 8153 (susceptible) & $155 \mathrm{~b}$ & $54 \mathrm{~b}$ & $0.8 \mathrm{c}$ \\
\hline
\end{tabular}

TYLCV $=$ Tomato yellow leaf curl virus; DSI = disease severity index.

${ }^{\mathrm{z}}$ Virus symptoms rated at $66 \mathrm{~d}$ after inoculation on a $0-4$ scale, where lower value indicated less disease; for scale and inoculation information, see Hutton et al. (2012).

${ }^{\text {y} M e a n ~ s e p a r a t i o n ~ i n ~ c o l u m n s ~ u s i n g ~ D u n c a n ' s ~ m u l t i p l e ~ r a n g e ~ t e s t ~ a t ~} P<0.05$. The experiment was a completely randomized block design with two blocks and five-plant plots. 


\section{Disease Resistance}

Fla. 7907C has resistance to TYLCV and other Begomoviruses against which $T y-1$ is effective (Table 4). It carries the $I, I-2$, and $I-3$ genes for resistance to fusarium wilt (Fusarium oxysporum f. sp. lycopersici) races 1, 2, and 3, respectively. It has the $S m$ gene that provides resistance to gray leaf spot (Stemphyllium sp.) and the $V e$ gene that confers resistance to verticillium wilt race 1 (Verticillium dahliae). Fla. 7907C is moderately susceptible to the fruit disorder graywall and symptomatic fruit can be found under conditions of moderate to high pressure for the disorder.
Availability

Seed of Fla.7907C is being released through the Florida Foundation Seed Producers, Inc. (FFSP), P.O. Box 309, Greenwood, FL 32443 (http://ffsp.net). If Fla. $7907 \mathrm{C}$ is used in developing other commercial hybrids, users should contact FFSP to discuss a royalty contract. Small quantities of seed for research purposes are available from S.F. Hutton under a material transfer agreement.

\section{Literature Cited}

Hutton, S.F., J.W. Scott, and D.J. Schuster. 2012. Recessive resistance to Tomato yellow leaf curl virus from the tomato cultivar Tyking is located in the same region as $T y-5$ on chromosome 4. HortScience 47:324-327.

Scott, J.W., E.A. Baldwin, H.J. Klee, J.K. Brecht, S.M. Olson, J.A. Bartz, and C.A. Sims. 2008. Fla. 8153 hybrid tomato; Fla. 8059 and Fla. 7907B breeding lines. HortScience 43:22282230.

Verlaan, M.G., S.F. Hutton, R.M. Ibrahem, R. Kormelink, R.G.F. Visser, J.W. Scott, J.D. Edwards, and Y. Bai. 2013. The tomato yellow leaf curl virus resistance genes $T y-1$ and $T y-3$ are allelic and code for DFDGDclass RNA-dependent RNA polymerases. PLoS Genet., 9(3):e1003399, doi: 10.1371/ journal.pgen.1003399. 